\title{
Disclosure of Sustainable Performance in Higher Education in Indonesia
}

\author{
Edwin Frymaruwah ${ }^{1}$ Evada Dewata ${ }^{1 ., *}$ Farah Aida Ahmad Nadzri² Periansya Periansya ${ }^{1}$ \\ ${ }^{1}$ Politeknik Negeri Sriwijaya, Palembang, Indonesia \\ ${ }^{2}$ Accounting Research Institute, UiTM, Malaysia \\ *Corresponding author. Email: evada78@polsri.ac.id
}

\begin{abstract}
This aim of this study is to examine the level of disclosure of the implementation of Sustainability Performance, especially for state higher education in Indonesia (profile, economic, environmental, social, educational). State universities with PTNBH status were the population, and 9 universities were the research samples for the period of 2017-2019. Data were collected using the Campus Sustainability Instrument or Graphical Assessment of Sustainability in Universities (GASU) and content analysis as an analytical technique covering the stages of decontextualization, recontextualization, categorization and compilation. The findings of this study show that the average level of disclosure on the Sustainability Performance of Indonesian universities is still low (42\% of all dimensions and indicators) with the highest level of disclosure on the educational dimension, followed by economic, profile, social and environmental dimensions, respectively. This research has practical implications for higher education management to strengthen disclosure as a form of commitment, transparency and credibility to stakeholders and to support the government for sustainable environmental development.
\end{abstract}

Keywords: Disclosure, Sustainability Performance, Higher Education, Universities, Stakeholder.

\section{INTRODUCTION}

University management, has a very important role in the application of environmental principles in higher education [2], because it can provide benefits to stakeholders and the larger social community [2] [6], is a "value builder of society" and "organizational organization". which have the effect of sustainable development" [7] and improve the internal quality of business processes within the organization [8].

The New Managerialism Philosophies (NMP) in education has increased the focus of state universities on financial, performance and business-oriented action targets [1]. The issue of sustainability performance in higher education is still showing an early diffusion stage in various regions around the world [2][3][4]. University management has a very important role in the application of environmental principles in higher education [2] because it can provide benefits to stakeholders and the larger social community [2] [6]. It is also a "value builder of society" and "organization which has the effect of sustainable development" [7]. In addition it improves the quality of internal business processes within the organization [8]

In Indonesia, the implementation of the concept of Sustainable Development Goals (SDGs) in higher education is starting to increase indicated by the implementation of sustainability reports in organizational reports similar to the mandate of Law Number 12 of 2012 that Legal Entity Higher Education Institution (PTNBH) as a university can be independent institution financially and can implement its research results to be used in the community. Legal Entity Higher Education Institutions (PTN-BH) have the highest possible autonomy in providing education. Regular publication is a form of transparency towards the environment and universities. However, the high management has not fully understood that sustainable reporting supports universities to be transparent regarding accountability and service obligations [9].

Thus, as an effort to improve the competitiveness of higher education institutions through increasing transparency and accountability and considering the role of universities in sustainable development such as environmentally friendly campus operations and social initiatives to improve the lives of communities around universities, this research aims to describe and examine the disclosure of the implementation of Sustainability Performance, especially for public higher education in Indonesia using the Graphical Assessment of Sustainability in Universities (GASU) method. 
This research is expected to contribute to higher education management in identifying the ability of universities to implement organizational sustainability performance, and for the Government, as information in collaborating with universities in the field of research and sustainable environmental development. This research is expected to contribute to higher education management in identifying the ability of universities to implement organizational sustainability performance. Besides, for the Government, it can be used as information in collaborating with universities in the field of research and sustainable environmental development.

\section{LITERATURE REVIEW}

Based on Stakeholder Theory, stakeholders have the right to obtain information about organizational activities that can influence their decision making. Higher Education Managers manage and control higher education not only based on economic motives, but also social motives. Higher education leaders must act as agents of all stakeholders and should communicate Sustainability Performance with all stakeholders through Sustainability Reporting [10]. All information on higher education in sustainable development must be accessible to all stakeholders; this can be realized through the disclosure of sustainability reports. In the context of sustainable reporting, universities can carry out Sustainability Reporting to meet information needs and convince stakeholders that universities have carried out operational activities that are in line with stakeholder interests.

Based on Legitimacy Theory, as a basis for reviewing the practice of sustainability reporting [11], organizations practice sustainability for not only social and environmental interests, but also a process of legitimizing (justifying) all activities carried out by the company. Sustainability Performance can be used by universities to build credibility and image of organizations, the community and the government can also assess the suitability of higher education operations with norms and values prevailing in society through sustainability reports. Legitimacy theory emphasizes that for organizations to gain stakeholder legitimacy, need to maintain congruence between stakeholder expectations and organizational goals.

\section{RESEARCH METHOD}

This is a qualitative research using a case study research design at state universities in Indonesia. The research population was 12 state universities with the status of Legal Entity State Universities (PTNBH) in Indonesia, and the research sample was $9 \mathrm{PTNBH}$, namely the Institut Teknologi Bandung (ITB), Institut Teknologi Sepuluh Nopember (ITS), Institut Pertanian Bogor (IPB), Universitas Indonesia (UI), Universitas Gadjah Mada (UGM), Universitas Padjajaran (Unpad), Universitas Airlangga (Unair), Universitas Sumatera Utara (USU), Universitas Pendidikan Indonesia (UPI). Graphical Assessment of Sustainability in Universities (GASU) was used as the research instrument [2] because it has become the main guideline for assessing the sustainability performance of a university [8]. A Likert scale is used to provide an assessment score for instrument disclosure. If information related to indicators does not exist or is not found in the PT report, the score is 0 , and if information is available for one indicator, the score is 1 . Secondary data for the period 2017-2019 were used with the assumption that if in 1 year, there is information about indicators; it is considered the same for all sample years. Secondary data sources were obtained from Financial Reports, University Annual Reports, Rector's Reports, Guidelines and Regulations related to financial management, university policies in the social and environmental fields and websites. The data were analyzed using content analysis which includes the stages of decontextualization, recontextualization, categorization and compilation.

\section{RESULTS AND DISCUSSIONS}

The Graphical Assessment of Sustainability in Universities (GASU) [2] provides an assessment of sustainability performance practices consisting of 5 dimensions, namely the profile, economic, environmental dimension, social dimension, and the education dimension. Table 1 provides information on the level of disclosure of each sustainability performance indicator.

Table 1. Disclosure of All Indicators in the Graphical Assessment of Sustainability in Universities (GASU)

\begin{tabular}{|c|c|c|c|c|c|c|c|c|c|c|}
\hline Dimensions and Indicators & ITB & ITS & IPB & UI & UGM & UNPAD & UNAIR & USU & UPI & $\begin{array}{c}\text { Total } \\
\text { (Average) }\end{array}$ \\
\hline \multicolumn{11}{|l|}{ PROFILE } \\
\hline Strategy and Analysis Organisational & $\sqrt{ }$ & $\sqrt{ }$ & $\sqrt{ }$ & $\sqrt{ }$ & $\sqrt{ }$ & $\sqrt{ }$ & $\sqrt{ }$ & $\sqrt{ }$ & $\sqrt{ }$ & 9 \\
\hline Profile Governance & & & & & & & & & & 0 \\
\hline Governance Commitments & & & & & & & & & & 0 \\
\hline Engagement Managament Approach and Performance & $\sqrt{ }$ & $\sqrt{ }$ & $\sqrt{ }$ & $\sqrt{ }$ & $\sqrt{ }$ & $\sqrt{ }$ & $\sqrt{ }$ & $\sqrt{ }$ & $\sqrt{ }$ & 9 \\
\hline Percentage of conformity & $50 \%$ & $50 \%$ & $50 \%$ & $50 \%$ & $50 \%$ & $50 \%$ & $50 \%$ & $50 \%$ & $50 \%$ & $50 \%$ \\
\hline
\end{tabular}




\begin{tabular}{|c|c|c|c|c|c|c|c|c|c|c|}
\hline Dimensions and Indicators & ITB & ITS & IPB & UI & UGM & UNPAD & UNAIR & USU & UPI & $\begin{array}{c}\text { Total } \\
\text { (Average) }\end{array}$ \\
\hline \multicolumn{11}{|l|}{ ECONOMIC } \\
\hline Economic performance & & & $\sqrt{ }$ & $\sqrt{ }$ & $\sqrt{ }$ & & $\sqrt{ }$ & $\sqrt{ }$ & $\sqrt{ }$ & 6 \\
\hline Market presence & & & $\sqrt{ }$ & $\sqrt{ }$ & $\sqrt{ }$ & & $\sqrt{ }$ & $\sqrt{ }$ & $\sqrt{ }$ & 6 \\
\hline Indirect economic impact & & $\sqrt{ }$ & $\sqrt{ }$ & $\sqrt{ }$ & $\sqrt{ }$ & $\sqrt{ }$ & $\sqrt{ }$ & $\sqrt{ }$ & $\sqrt{ }$ & 8 \\
\hline Percentage of conformity & $0 \%$ & $33 \%$ & $100 \%$ & $100 \%$ & $100 \%$ & $33 \%$ & $100 \%$ & $100 \%$ & $100 \%$ & $74 \%$ \\
\hline \multicolumn{11}{|l|}{ ENVIRONMENTAL } \\
\hline Materials & & & & & & & & & & 0 \\
\hline Energy & & & & & & & & & & 0 \\
\hline Water & & & & & & & & & & 0 \\
\hline Biodiversity & & & & & & & & & & 0 \\
\hline Emissions, effluents and waste & & & & & & & & & & 0 \\
\hline Products and Service & & $\sqrt{ }$ & $\sqrt{ }$ & $\sqrt{ }$ & $\sqrt{ }$ & & & & $\sqrt{ }$ & 5 \\
\hline Compliance & & & $\sqrt{ }$ & $\sqrt{ }$ & $\sqrt{ }$ & $\sqrt{ }$ & & $\sqrt{ }$ & $\sqrt{ }$ & 6 \\
\hline Transport & & & $\sqrt{ }$ & $\sqrt{ }$ & $\sqrt{ }$ & $\sqrt{ }$ & & $\sqrt{ }$ & $\sqrt{ }$ & 6 \\
\hline Overall & $\sqrt{ }$ & & $\sqrt{ }$ & $\sqrt{ }$ & $\sqrt{ }$ & & & & & 4 \\
\hline Percentage of conformity & $11 \%$ & $11 \%$ & $44 \%$ & $44 \%$ & $44 \%$ & $33 \%$ & $0 \%$ & $22 \%$ & $33 \%$ & $27 \%$ \\
\hline \multicolumn{11}{|l|}{ SOCIAL } \\
\hline Labour Practices and Decent Work & & & $\sqrt{ }$ & $\sqrt{ }$ & $\sqrt{ }$ & & $\sqrt{ }$ & $\sqrt{ }$ & & 5 \\
\hline Human rights & & & $\sqrt{ }$ & & $\sqrt{ }$ & & & & & 2 \\
\hline Society & & & $\sqrt{ }$ & $\sqrt{ }$ & $\sqrt{ }$ & & & & & 3 \\
\hline Product responsibility & & & $\sqrt{ }$ & $\sqrt{ }$ & $\sqrt{ }$ & & & & $\sqrt{ }$ & 4 \\
\hline Percentage of conformity & $0 \%$ & $0 \%$ & $100 \%$ & $75 \%$ & $100 \%$ & $0 \%$ & $25 \%$ & $25 \%$ & $25 \%$ & $39 \%$ \\
\hline \multicolumn{11}{|l|}{ EDUCATIONAL } \\
\hline Curriculum & & & $\sqrt{ }$ & $\sqrt{ }$ & $\sqrt{ }$ & & $\sqrt{ }$ & & $\sqrt{ }$ & 5 \\
\hline Research & $\sqrt{ }$ & & $\sqrt{ }$ & $\sqrt{ }$ & $\sqrt{ }$ & & & $\sqrt{ }$ & & 5 \\
\hline Percentage of conformity & $50 \%$ & $0 \%$ & $100 \%$ & $100 \%$ & $100 \%$ & $100 \%$ & $100 \%$ & $100 \%$ & $100 \%$ & $100 \%$ \\
\hline Total Indicators & 22 & 22 & 22 & 22 & 22 & 22 & 22 & 22 & 22 & \\
\hline Total Indicators Reported & 4 & 4 & 15 & 14 & 15 & 5 & 7 & 9 & 10 & 9.22 \\
\hline Percentage of conformity & $18 \%$ & $18 \%$ & $68 \%$ & $64 \%$ & $68 \%$ & $23 \%$ & $32 \%$ & $41 \%$ & $45 \%$ & $42 \%$ \\
\hline
\end{tabular}

Source: Data Processing, 2021

As shown in Table 1, the results of content analysis indicate that the dimension that has the highest level of disclosure is the educational dimension $(100 \%)$. This is because the curriculum and research indicators are information that is commonly disclosed by universities. These findings indicate that state universities with PTNBH status already have good sustainability performance in the field of education. Curriculum indicators state that universities already have a curriculum that includes sustainability topics such as social and environmental accounting topics, and this curriculum is a routine activity of universities as education providers in maintaining the quality of education, as supported [4] and [12]. In addition, research indicator is one of the main activities of universities, and research topics or publications have led to the topic of sustainability.

Disclosure of the Economic dimension (74\%) is quite high. The results of this study support [8], and prove that most universities have realized the importance of maintaining campus sustainability in order to improve the internal quality of business processes within the organization.

The Profile dimension shows that the level of disclosure is not good enough $(50 \%)$. This is because most universities do not have documents that contain statements of sustainability policies such as social, environmental and economic. As stated [14], the greater the number of sustainability-specific terms used in a university's mission statement, the higher the statistical probability that the university has a sustainability disclosure rating. This finding does not confirm [13] that it is important for universities to build institutional profile information and there is a need for a committee responsible for reporting and sustainability issues.

The Social dimension (39\%) indicates that universities still have not reported information related to Labor Practices and Decent Work, Human rights, Society and Product responsibility. The results of this study reveal that universities do not focus on social information and university management has not implemented sustainability programs as part of the university's long-term plan. The results of this study support the findings [4] that the low disclosure in universities is because universities do not carry out practices related to information in indicators, and documentation factors are less integrated.

The disclosure of Environmental dimensions (27\%) is at the lowest level. Several indicators such as materials, energy, water, biodiversity, and emissions, effluents and waste and other types of environmental costs are relatively rare in educational sector organizations because the core business of universities does not produce products and hazardous waste to the 
surrounding environment. The results of the research have not been coherent as proposed by [13]. In additiom, there is a tendency for the process of documenting environmental dimension indicators to be continuously carried out and disclosed by universities [2]. The low disclosure of the environmental dimension also happens because the disclosure of information at universities in Indonesia is still in a limited scope, and information can only be accessed by certain parties within the scope.

Table 1 also shows that generally Indonesian universities have disclosed $42 \%$ of all dimensions and indicators. This means that the current level of disclosure of Sustainability Performance is not sufficiently broad in scope and information although the results of this study are quite large compared to the findings [12] as $37 \%$.

The universities with the most comprehensive disclosures are Universitas Gadjah Mada (UGM) (68\% conforming the indicator), and Institut Pertanian Bogor (IPB) (68\% conforming the indicator), and only $33 \%$ (3) universities have the percentage of conformity above $50 \%$. It can be concluded that the disclosure of sustainability information by state universities with PTNBH status in Indonesia is still relatively low. This finding indicates that state universities in Indonesia have not fully understood the importance of sustainability in implementing more environmentally friendly policies, as revealed [15] that university management must understand that the concept of sustainability is part of the university's long-term strategic plan.

The results of this study do not support the legitimacy theory that the legitimacy process of all activities carried out by universities practicing sustainability must take sides with social and environmental interests. The results of this study have implications for higher education management to be committed to building the credibility and image of universities by developing education that cares about the environment in accordance with applicable norms and values.

The results of this study also do not support the Stakeholder Theory as of the 9 research samples only a few universities have disclosed sustainability information in one report, because there is no need/obligation for universities to issue an integrated sustainability report. Meanwhile, according to Stakeholder Theory, stakeholders have the right to obtain information about the university's long-term plans and policies. Higher education leaders should communicate Sustainability Performance with stakeholders in a Sustainability Reporting. The findings in the field also show some difficulties related to sustainable development information that is not yet widely accessible. Furthermore, most universities have carried out sustainability, but they rarely report it for the needs of stakeholders, while universities are obliged to educate the public about the impact of their operations on the environment.

\section{CONCLUSION}

The results showed that the level of disclosure of Sustainability Performance conducted by state universities with PTNBH status in Indonesia was still low at an average of $47 \%$. State universities in Indonesia do not fully understand the importance of implementing more environmentally friendly policies as part of the university's long-term strategic plan. One of the obstacles in the process of implementing the concept of sustainability in universities is the absence of standards or guidelines for implementing the concept of sustainability in universities. The implication of this research is for university management to continue to be committed to encouraging sustainability accounting practices and disclosures in universities. The limitations of this study are (1) the difficulty of obtaining published data such as universities' annual reports and the rectors' reports, and (2) the needs for adjustment of the GASU instrument to assess the sustainability of higher education institutions because there are several indicators in GASU that are not implemented by universities especially in Indonesia which can be a topic for further research.

\section{ACKNOWLEDGMENTS}

Thank you to Polytechnic State of Sriwijaya for supporting and facilitating the Overseas Collaborative Research team by providing PNBP Research grants for 2021.

\section{REFERENCES}

[1] Lynch, K. (2015). Control by numbers: new managerialism and ranking in higher education. Critical Studies in Education, 56(2), 190-207.

[2] Lozano, R. (2011). The State of Sustainability Reporoting in Universities. International Journal Of Sustainability In Higher Education, 12(1), 6778 .

[3] Del Mar Alonso-Almeida, M., Marimon, F., Casani, F., \& Rodriguez-Pomeda, J. (2015). Diffusion of sustainability reporting in universities: current situation and future perspectives. Journal of Cleaner Production, 106, 144-154.

[4] Yasbie, B., \& Barokah, Z. (2018). Sustainability Reporting By Universities In Indonesia Abstract. The Indonesian Journal of Accounting Research, 21(3). 
[5] Ernst \& Young Global Limited (2013). Value of Sustainability Reporting. A study by Ernst \& Young LLP and the Boston College Center for Corporate Citizenship

[6] Jusuf, E., Herwany, A., Kurniawan, P. S., \& Gunardi, A. (2020). Sustainability concept implementation in higher education institutions of Indonesia. Journal of

[7] Godemann, Jasmin, Jan Bebbington, Christian Herzig, dan Jeremy Moon. (2014). "Higher Education and Sustainable Development Exploring Possibilities for Organisational Change.” Accounting Auditing \& Accountability Journal $27 \quad$ (2): $218-33$. https://doi.org/10.1108/AAAJ-12- 2013-1553.

[8] Kurniawan, P. S. (2020). Sustainability Accounting Concept in Higher Education Institution: A Case Study of an Indonesian Public University. Jurnal Ilmiah Akuntansi dan Bisnis, 15(2), 213-233.

[9] Alonso-Almeida, Maria del Mar, Frederic Marimon, Fernando Casani, dan Jesus RodriguezPomeda. (2014). "Diffusion of Sustainability Reporting in Universities: Current Situation and Future erspectives." Journal of Cleaner Production 106: 144-54. https://doi.org/10.1016/j.jclepro.2014.02.008

[10] Adams, C. A. (2013). "Sustainability reporting and performance management in universities: Challenges and benefits," Sustainability Accounting, Management and Policy Journal 4: 384-392.

[11] Tilling, M. V. (2004). Refinements to Legitimacy Theory in Social and Environmental Accounting. Commerce Research Paper Series No. 04-6, http://www.sn.flinders.edu.au/business/research/ papers/04-6.pdf

[12] Fonseca, A., Macdonald, A., Dandy, E., \& Valenti, P. (2011). The State of Sustainability Reporting At Canadian Universities. International Journal of Sustainability In Higher Education.

[13] Gutierrez, D. G., \& Sepulveda, J. A. M. (2018). Sustainability Indicators for Universities: Revision for a Colombian Case. Global Journal of Research In Engineering.

[14] Lopez, Y. P., \& Martin, W. F. (2018). University mission statements and sustainability performance. Business and society review, 123(2), 341-368.

[15] Jusuf, E., Herwany, A., Kurniawan, P. S., \& Gunardi, A. (2020). Sustainability concept implementation in higher education institutions of Indonesia. Journal of Southwest Jiaotong University, 55(1). 